\title{
Two SNPs in the promoter region of Toll-like receptor 4 gene are not associated with smoking in Saudi Arabia
}

This article was published in the following Dove Press journal:

OncoTargets and Therapy

9 February 2017

Number of times this article has been viewed

\author{
Muhammad Kohailan' \\ Mohammad Alanazi' \\ Mahmoud Rouabhia ${ }^{2}$ \\ Abdullah Al Amri \\ Narasimha Reddy Parine' \\ Abdelhabib Semlali' \\ 'Department of Biochemistry, \\ College of Science, King Saud \\ University, Riyadh, Kingdom of Saudi \\ Arabia; ${ }^{2}$ Groupe de Recherche en \\ Écologie Buccale, Département de \\ Stomatologie, Faculté de Médecine \\ Dentaire, Université Laval, Québec, \\ QC, Canada
}

\begin{abstract}
Defects in the innate immune system, particularly in Toll-like receptors (TLRs), have been reported in several cigarette smoke-promoted diseases. The aim of this study was to examine the impact of tobacco smoke on allelic frequencies of TLR4 single-nucleotide polymorphisms (SNPs) and to compare the genotypic distribution of these SNPs in a Saudi Arabian population with that in previously studied populations. DNA was extracted from 303 saliva samples collected from smokers and nonsmokers. Two transitional SNPs in the promoter region of TLR4 were selected, rs2770150 (T/C) and rs10759931 (G/A). Genotype frequencies were determined using quantitative polymerase chain reaction. Our results showed a slight effect of smoking on the distribution of rs 2770150 and rs10759931. However, the differences were not significant. Thus, we conclude that the SNPs selected for this study were independent of smoking and may not be related to smoking-induced diseases.
\end{abstract}

Keywords: Toll-like receptor 4, polymorphism, genetic variation, smoking

\section{Introduction}

Innate immunity, which is considered to be the first line of defense against diseases, is well studied, and its role has been clarified through study of mutations in innate immunity genes as well as of patients with various diseases such as cystic fibrosis. ${ }^{1}$ In addition to induction of autoimmune diseases, ${ }^{2}$ defects in the innate immune system have been reported in several other diseases such as types of cancer, ${ }^{3}$ asthma, ${ }^{4}$ psoriasis, ${ }^{5}$ and Alzheimer's and other neurodegenerative diseases. ${ }^{6,7}$ The innate immune system initially recognizes microorganisms through pattern recognition receptors, in particular Toll-like receptors (TLRs). ${ }^{8}$ TLRs are a family of at least 13 transmembrane receptors that are expressed on immune cells as well as on gingival epithelial cells and are involved in the initiation of inflammatory processes..$^{9-11}$ Upon induction by certain ligands, TLRs activate intracellular signaling pathways that promote the production of multiple immune mediators that contribute to host defense. ${ }^{12,13}$ Several polymorphisms have been reported at different positions in TLR genes ${ }^{14,15}$ and were found to be associated with inflammatory diseases. ${ }^{16,17}$ Single-nucleotide polymorphisms (SNPs) are a class of polymorphisms involving single-base substitutions. ${ }^{18}$ SNPs are thought to constitute the majority of sequence variants in human beings, ${ }^{19}$ and they occur approximately once every 300 bases. ${ }^{20}$ Several reports have demonstrated the role of TLR SNPs in the development of cancer. ${ }^{21,22}$ TLR4, which is located on chromosome 9, encodes a protein that plays a critical role in the immune system through recognition of lipopolysaccharides found in Gram-negative bacteria. ${ }^{23,24}$ TLR4 polymorphisms have been reported to be 
involved in different infectious and noninfectious diseases. ${ }^{25,26}$ In particular, the TLR4 SNPs rs2770150 and rs10759931 have been detected in association with many health complications. We previously demonstrated that TLR4 polymorphisms, specifically the SNPs rs2770150 and rs10759931, are associated with colon cancer. ${ }^{27}$ Additionally, variations in the rs 2770150 SNP were found to affect antibody response to whole-cell pertussis vaccination. ${ }^{28}$ Furthermore, these variations alter the level of susceptibility to pollution-induced asthma. ${ }^{29}$ The rs10759931 SNP was demonstrated to be associated with latent tuberculosis infection and subsequent pulmonary tuberculosis. ${ }^{30}$ Many of these diseases have been shown to be caused by tobacco smoke, indicating the importance of examining the effects of smoking on these SNPs. ${ }^{31-33}$ The huge number of health problems and risks associated with tobacco smoke are widely known, including COPD, ${ }^{34}$ different types of cancer, ${ }^{35,36}$ and periodontal diseases ${ }^{37}$ Smoking was found to induce epigenetic and genetic alterations that, in turn, may lead to the initiation of different diseases, including those described earlier. ${ }^{38}$ Smoking may cause either transition or transversion mutations. ${ }^{39}$ However, transitions are reported to generate more radical amino acid changes than transversions. ${ }^{40}$ The aim of this study was to examine the impact of tobacco smoke on allelic frequencies of TLR4 rs2770150 and rs10759931 transitional SNPs and to compare the genotypic distribution of these SNPs in a Saudi Arabian population with that in other previously studied populations.

\section{Materials and methods Saliva collection}

Saliva samples were collected from a total of 126 nonsmokers and 177 smokers. Samples were collected from male students and staff at King Saud University (KSU) between January and April 2015. From each participant, $2 \mathrm{~mL}$ of saliva was collected in a $15-\mathrm{mL}$ falcon tube. The clinical data for these samples are listed in Table 1. This study was reviewed by the College of Applied Medical Sciences' research ethics committee at KSU and was granted the approval number CAMS 13/3536. Each participant provided informed consent and completed a written survey. Data included in the survey comprised age, number of cigarettes smoked per day, years of smoking, and body mass index (BMI).

\section{DNA extraction}

Each saliva sample was diluted with two volumes of phosphate-buffered saline immediately after collection. DNA extraction was performed using the PureLink Genomic DNA Mini Kit (Invitrogen, Carlsbad, CA, USA). A NanoDrop
Table I Clinical characteristics of study subjects

\begin{tabular}{lll}
\hline Variable & $\begin{array}{l}\text { Nonsmokers } \\
(\mathbf{n}=\mathbf{I} 26)\end{array}$ & $\begin{array}{l}\text { Smokers } \\
(\mathbf{n}=\mathbf{I} 77)\end{array}$ \\
\hline $\begin{array}{l}\text { Age (years), median } \pm \text { average } \\
\text { BMI }\end{array}$ & $20 \pm 21$ & $24 \pm 27$ \\
$\quad$ Obese $\left(\geq 30 \mathrm{~kg} / \mathrm{m}^{2}\right)$ & $20 / 100(20 \%)$ & $27 / 163(17 \%)$ \\
$\quad$ Nonobese $\left(<30 \mathrm{~kg} / \mathrm{m}^{2}\right)$ & $80 / 100(80 \%)$ & $136 / 163(83 \%)$ \\
$\begin{array}{l}\text { Years of smoking } \\
>5\end{array}$ & - & $104 / 165(63 \%)$ \\
$\quad \leq 5$ & - & $61 / 165(37 \%)$ \\
$\begin{array}{l}\text { Cigarettes per day } \\
\quad 20\end{array}$ & - & $99 / 159(62.3 \%)$ \\
$\quad<20$ & - & $60 / 159(37.7 \%)$ \\
\hline
\end{tabular}

Abbreviation: BMl, body mass index.

8000 spectrophotometer (Thermo Fisher Scientific, Waltham, MA, USA) was used to determine the DNA concentration and quality. Then, the DNA samples were stored at $-20^{\circ} \mathrm{C}$ for later application.

\section{Genotyping}

Each DNA sample was diluted to $10 \mathrm{ng} / \mu \mathrm{L}$ before use in the genotyping experiments. Two transitional TLR4 SNPs were selected: rs2770150 (T/C) and rs10759931 (G/A). Few data are available regarding the association of the selected SNPs with different diseases. However, these SNPs were selected because they occur in the promoter region (Table 2) and thus regulate TLR4 expression. Reactions were performed using $20 \mathrm{ng}$ of DNA mixed with $5.6 \mu \mathrm{L}$ of TaqMan ${ }^{\circledR}$ Genotyping Master Mix (Applied Biosystems, Foster City, CA, USA) and $0.2 \mu \mathrm{L}$ of $40 \times$ TaqMan $^{\circledR}$ SNP Genotyping assay (Applied Biosystems), using a QuantStudio ${ }^{\text {TM }} 7$ Flex Real-Time PCR System thermal cycler (Applied Biosystems). The amplification protocol included 40 cycles as follows: a preread stage for $30 \mathrm{sec}$ at $60^{\circ} \mathrm{C}$, a hold for $10 \mathrm{~min}$ at $95^{\circ} \mathrm{C}$, amplification for $15 \mathrm{sec}$ at $95^{\circ} \mathrm{C}$ and $1 \mathrm{~min}$ at $60^{\circ} \mathrm{C}$, and a post-read stage for $30 \mathrm{sec}$ at $60^{\circ} \mathrm{C}$.

\section{Statistical analysis}

Genotypic and allelic frequencies were calculated and checked for deviation from Hardy-Weinberg equilibrium, as described in our previous work. ${ }^{41}$ Case-control and other

Table 2 Description of the selected SNPs

\begin{tabular}{|c|c|c|c|c|}
\hline Gene & SNP ID & SNP location & $\begin{array}{l}\text { SNP } \\
\text { type }\end{array}$ & $\begin{array}{l}\text { Ancestral } \\
\text { allele }\end{array}$ \\
\hline \multirow[t]{2}{*}{ TLR4 } & rs2770I50 & NC_000009.II:g.120463139 & Promoter & $\mathrm{T}>\mathrm{C}$ \\
\hline & rsl0759931 & NC_000009.II:g.120464I47 & Promoter & $\mathrm{G}>\mathrm{A}$ \\
\hline
\end{tabular}


genetic comparisons were performed using the chi-square test and allelic odds ratios (ORs), and 95\% confidence intervals (CIs) were calculated with Fisher's exact test (two-tailed). Statistical analyses were performed using Statistical Package for the Social Sciences (SPSS) 22.0 software (SPSS, Chicago, IL, USA). $P$-values $\leq 0.05$ were considered significant.

\section{Results}

\section{Characteristics of the study population}

As shown in Table 1, the smokers and nonsmokers did not differ significantly in BMI, because the selection criteria for this study were independent of patient weight. In addition, approximately two-thirds of the samples were collected from students rather than staff, and the smoker and nonsmoker groups did not differ significantly in age. Thus, no genotyping analysis was conducted regarding these parameters. Given that the average age at which participants started smoking was 18.3 years and that half of the smokers $(85 / 176)$ were less than 24 years of age, we separated the smoker participants into the following two groups: those who had smoked for $>5$ years and those who had smoked for $\leq 5$ years. Approximately half of the smokers (71/159) consume 20 cigarettes (ie, one pack) per day, and we classified the smokers into the following two categories: those who consume $\geq 20$ cigarettes per day and those who daily consume $<20$ cigarettes. The characteristics of the subjects are summarized in Table 1.

\section{Genotypic patterns of TLR4 SNPs among smokers and nonsmokers}

A total of 303 saliva samples, 177 from smokers and 126 from nonsmokers, were included in this study to investigate the effects of tobacco smoke on the genotypic distribution of TLR 4 rs2770150 and rs10759931 SNPs. The homozygous ancestral alleles, TT in rs2770150 and AA in rs10759931, were used as references for the genotyping analysis. The allelic frequencies in nonsmokers and smokers, ORs, 95\% CIs, chi-square results, and $P$-values are listed in Table 3. Neither SNP was significantly associated with smoking behavior. The genotypic distribution of rs2770150 was 49\% TT, 38\% TC, and 13\% CC in nonsmokers compared to $54 \% \mathrm{TT}, 35 \% \mathrm{TC}$, and $11 \% \mathrm{CC}$ in smokers. The allele frequencies for rs 10759931 were $12 \% \mathrm{AA}, 32 \% \mathrm{AG}$, and $56 \% \mathrm{GG}$ in nonsmokers and 8\% AA, 37\% AG, and 55\% GG in smokers.

\section{Long- and short-term smoking and their impacts on TLR4 polymorphisms}

The smokers were divided into two groups based on years of smoking: group A ( $>5$ years) and group B ( $\leq 5$ years). Table 4 lists the genotypic frequencies and subsequent analysis of the SNPs for each group compared to nonsmokers. No correlation was observed between the SNPs and either long-term or short-term smokers. The genotypic allocation of the rs2770150 SNP in group A was 49\% TT, 38\% TC, and $13 \% \mathrm{CC}$ in nonsmokers and 57\% TT, 34\% TC, and 9\% $\mathrm{CC}$ in smokers. In group B, however, 53\% TT, 33\% TC, and $15 \%$ CC were observed in smokers compared to $49 \% \mathrm{TT}$, $38 \%$ TC, and 13\% CC in nonsmokers. For the rs10759931 $\mathrm{SNP}$, the genotypic frequencies in group A were 12\% AA, $32 \% \mathrm{AG}$, and $56 \% \mathrm{GG}$ in nonsmokers and $8 \% \mathrm{AA}, 36 \% \mathrm{AG}$, and $56 \% \mathrm{GG}$ in smokers. Allele frequencies for this SNP in group B were $8 \%$ AA, 32\% AG, and 59\% GG in smokers and $12 \%$ AA, $32 \% \mathrm{AG}$, and $56 \%$ GG in nonsmokers.

Table 3 Genotype frequencies of TLR4 gene polymorphism in smoker and control patients

\begin{tabular}{|c|c|c|c|c|c|c|c|c|}
\hline Gene & SNP & Allele & Nonsmokers, n (\%) & Smokers, n (\%) & OR & $95 \% \mathrm{Cl}$ & $\chi^{2}$ & $P$-value \\
\hline \multirow[t]{14}{*}{ TLR4 } & rs 2770150 & Total & 112 & 156 & & & & \\
\hline & & $\mathrm{TT}$ & $55(0.49)$ & $85(0.54)$ & Ref & & & \\
\hline & & $\mathrm{TC}$ & $43(0.38)$ & $54(0.35)$ & 0.81 & $0.4807-1.3735$ & 0.6012 & $0.438 \mathrm{I}$ \\
\hline & & $\mathrm{CC}$ & $14(0.13)$ & $17(0.11)$ & 0.79 & $0.3586-1.7217$ & 0.3640 & 0.5463 \\
\hline & & $\mathrm{TC}+\mathrm{CC}$ & $57(0.5 \mathrm{I})$ & 7I $(0.46)$ & 0.81 & $0.4956-1.3108$ & 0.7563 & 0.3845 \\
\hline & & $\mathrm{T}$ & $153(0.68)$ & $224(0.72)$ & Ref & & & \\
\hline & & $\mathrm{C}$ & $71(0.32)$ & $88(0.28)$ & 0.85 & $0.5823-1.2308$ & 0.7617 & 0.3828 \\
\hline & rsI075993I & Total & 118 & 168 & & & & \\
\hline & & AA & $14(0.12)$ & $13(0.08)$ & Ref & & & \\
\hline & & AG & $38(0.32)$ & $62(0.37)$ & 1.76 & $0.7464-4.1362$ & 1.6870 & 0.1940 \\
\hline & & GG & $66(0.56)$ & $93(0.55)$ & 1.52 & $0.6696-3.4392$ & 1.0072 & 0.3156 \\
\hline & & $A G+G G$ & $104(0.88)$ & $155(0.92)$ & 1.61 & $0.7250-3.5534$ & 1.3804 & 0.2400 \\
\hline & & $A$ & $66(0.28)$ & $88(0.26)$ & Ref & & & \\
\hline & & G & I $70(0.72)$ & $248(0.74)$ & 1.09 & $0.7527-1.5905$ & 0.2222 & 0.6374 \\
\hline
\end{tabular}

Abbreviations: TLR, Toll-like receptor; SNP, single-nucleotide polymorphism; OR, odds ratio; Cl, confidence interval. 
Table 4 Comparison of genotype frequencies of TLR4 gene SNPs with overall controls depending on smoking duration

\begin{tabular}{|c|c|c|c|c|c|c|c|c|}
\hline Gene & SNP & Allele & Nonsmokers, n (\%) & Smokers, n (\%) & OR & $95 \% \mathrm{Cl}$ & $\chi^{2}$ & $P$-value \\
\hline \multirow[t]{16}{*}{ TLR4 } & rs 2770150 & Patients smoking for $>5$ years & & & & & & \\
\hline & & Total & 112 & 91 & & & & \\
\hline & & $\mathrm{TT}$ & $55(0.49)$ & $52(0.57)$ & Ref & & & \\
\hline & & TC & $43(0.38)$ & $31(0.34)$ & 0.76 & $0.4195-1.3859$ & 0.7924 & 0.3734 \\
\hline & & $\mathrm{CC}$ & $14(0.13)$ & $8(0.09)$ & 0.60 & $0.2343-1.5594$ & 1.0979 & 0.2947 \\
\hline & & $\mathrm{TC}+\mathrm{CC}$ & $57(0.5 \mathrm{I})$ & $39(0.43)$ & 0.72 & $0.4 \mid 49-1.2624$ & 1.3006 & 0.2541 \\
\hline & & $\mathrm{T}$ & $153(0.68)$ & $135(0.74)$ & Ref & & & \\
\hline & & C & $71(0.32)$ & $47(0.26)$ & 0.75 & $0.4855-1.1593$ & 1.6795 & 0.1950 \\
\hline & rs2770I50 & Patients smoking for $\leq 5$ years & & & & & & \\
\hline & & Total & 112 & 55 & & & & \\
\hline & & TT & $55(0.49)$ & $29(0.53)$ & Ref & & & \\
\hline & & $\mathrm{TC}$ & $43(0.38)$ & $18(0.33)$ & 0.79 & $0.3901-1.6159$ & 0.4058 & 0.5241 \\
\hline & & $\mathrm{CC}$ & $14(0.13)$ & $8(0.15)$ & 1.08 & $0.4075-2.8825$ & 0.0260 & 0.8720 \\
\hline & & $\mathrm{TC}+\mathrm{CC}$ & $57(0.5 \mathrm{I})$ & $26(0.47)$ & 0.87 & $0.4534-1.6507$ & 0.1934 & 0.6601 \\
\hline & & $\mathrm{T}$ & $153(0.68)$ & $76(0.69)$ & Ref & & & \\
\hline & & $A$ & $170(0.72)$ & $146(0.74)$ & 1.09 & $0.7123-1.6680$ & 0.1578 & 0.6912 \\
\hline \multirow[t]{16}{*}{ TLR4 } & rsl075993I & Patients smoking for $>5$ years & & & & & & \\
\hline & & Total & 118 & 99 & & & & \\
\hline & & AA & $14(0.12)$ & $8(0.08)$ & Ref & & & \\
\hline & & AG & $38(0.32)$ & $36(0.36)$ & 1.66 & $0.6216-4.4219$ & 1.0309 & 0.3099 \\
\hline & & GG & $66(0.56)$ & $55(0.56)$ & 1.46 & $0.5700-3.73 \mid 4$ & 0.6242 & 0.4295 \\
\hline & & $A G+G G$ & $104(0.88)$ & 91 (0.92) & 1.53 & $0.6145-3.8159$ & 0.8459 & 0.3577 \\
\hline & & $A$ & $66(0.28)$ & $52(0.26)$ & Ref & & & \\
\hline & & G & $170(0.72)$ & $146(0.74)$ & 1.09 & $0.7123-1.6680$ & 0.1578 & 0.6912 \\
\hline & rs I075993। & Patients smoking for $\leq 5$ years & & & & & & \\
\hline & & Total & 118 & 59 & & & & \\
\hline & & AA & $14(0.12)$ & $5(0.08)$ & Ref & & & \\
\hline & & AG & $38(0.32)$ & $19(0.32)$ & 1.40 & $0.4388-4.4667$ & 0.3248 & 0.5687 \\
\hline & & GG & $66(0.56)$ & $35(0.59)$ & 1.48 & $0.494 \mid-4.462 I$ & 0.5003 & 0.4794 \\
\hline & & $A G+G G$ & $104(0.88)$ & $54(0.92)$ & 1.45 & $0.4973-4.2502$ & 0.4717 & 0.4922 \\
\hline & & $A$ & $66(0.28)$ & $29(0.25)$ & Ref & & & \\
\hline & & G & $170(0.72)$ & $89(0.75)$ & 1.19 & $0.7181-1.9770$ & 0.4604 & 0.4974 \\
\hline
\end{tabular}

Abbreviations: TLR, Toll-like receptor; SNP, single-nucleotide polymorphism; OR, odds ratio; Cl, confidence interval.

\section{Association between individual SNPs and the intensity of smoking}

Allele frequency data for the smokers were also analyzed with regard to the quantity of cigarettes consumed per day. Here, we identified two categories: category $A$ ( $\geq 20$ cigarettes/day) and category $\mathrm{B}$ ( $<20$ cigarettes/day). The SNP genotypes of both categories of smokers were compared to those of nonsmokers (Table 5); no significant differences were observed. For the rs $2770150 \mathrm{SNP}$, the genotypes of smokers in category A were $61 \%$ TT, 29\% TC, and 10\% CC and the genotypes of smokers in category B were $45 \% \mathrm{TT}, 42 \% \mathrm{TC}$, and $13 \%$ $\mathrm{CC}$. Both categories were compared to nonsmokers, in whom the allele frequencies were $49 \% \mathrm{TT}, 38 \% \mathrm{TC}$, and $13 \% \mathrm{CC}$. For the rs 10759931 SNP, nonsmokers showed allele frequencies of $12 \%$ AA, $32 \%$ AG, and $56 \%$ GG. The genotypic distribution of category A smokers for this SNP was 9\% $\mathrm{AA}, 37 \% \mathrm{AG}$, and $54 \% \mathrm{GG}$. In category B smokers for the same SNP, the allele frequencies were $7 \% \mathrm{AA}, 33 \% \mathrm{AG}$, and $60 \% \mathrm{GG}$.

\section{Differentiation between the Saudi Arabian population and others and linkage studies}

The genotyping results for nonsmokers were used to compare the Riyadh region population in Saudi Arabia (CRS), from which we collected our samples, with other previously studied populations (Table 6). Of 126 samples, we determined the rs 2770150 SNP genotypes for 112 samples and the rs 10759931 SNP genotypes for 118 samples. The frequency of the various alleles of rs2770150 differed significantly between Chinese (Han Chinese in Beijing), Japanese (Japanese in Tokyo), Nigerian (Yoruba in Ibadan), Kenyan (Maasai in Kinyawa), and Italian (Toscans) populations, and the Saudi population $(P<0.005$ for most). For TLR4 rs10759931, the CRS population differed significantly from African Americans (D-0) and North Americans 
Table 5 Genotype frequencies of TLR4 gene SNPs with overall controls according to the daily quantity of cigarettes

\begin{tabular}{|c|c|c|c|c|c|c|c|c|}
\hline Gene & SNP & Allele & Nonsmokers, n (\%) & Smokers, n (\%) & OR & $95 \% \mathrm{Cl}$ & $\chi^{2}$ & $P$-value \\
\hline \multirow[t]{16}{*}{ TLR4 } & rs $2770 I 50$ & Patients smoking $\geq \mathbf{2 0}$ cigarettes/day & & & & & & \\
\hline & & Total & 112 & 87 & & & & \\
\hline & & TT & $55(0.49)$ & $53(0.61)$ & Ref & & & \\
\hline & & $\mathrm{TC}$ & $43(0.38)$ & $25(0.29)$ & 0.60 & $0.3243-1.1224$ & 2.5621 & 0.1095 \\
\hline & & $\mathrm{CC}$ & $14(0.13)$ & $9(0.10)$ & 0.67 & $0.2663-1.67 \mid 4$ & 0.7521 & 0.3858 \\
\hline & & $\mathrm{TC}+\mathrm{CC}$ & $57(0.5 \mathrm{I})$ & $34(0.39)$ & 0.62 & $0.3507-1.0925$ & 2.7530 & $0.097 \mid$ \\
\hline & & $\mathrm{T}$ & $153(0.68)$ & $|3|(0.75)$ & Ref & & & \\
\hline & & C & $71(0.32)$ & $43(0.25)$ & 0.71 & $0.4534-1.1036$ & 2.3369 & 0.1263 \\
\hline & rs $2770 I 50$ & Patients smoking $<20$ cigarettes/day & & & & & & \\
\hline & & Total & 112 & 53 & & & & \\
\hline & & TT & $55(0.49)$ & $24(0.45)$ & Ref & & & \\
\hline & & $\mathrm{TC}$ & $43(0.38)$ & $22(0.42)$ & 1.17 & $0.5806-2.3676$ & 0.1971 & $0.657 \mid$ \\
\hline & & $\mathrm{CC}$ & $14(0.13)$ & $7(0.13)$ & 1.15 & $0.4106-3.1974$ & 0.0677 & 0.7948 \\
\hline & & $\mathrm{TC}+\mathrm{CC}$ & $57(0.5 \mathrm{I})$ & $29(0.55)$ & 1.17 & $0.6053-2.2459$ & 0.2108 & 0.6461 \\
\hline & & $\mathrm{T}$ & $153(0.68)$ & $70(0.66)$ & Ref & & & \\
\hline & & C & $71(0.32)$ & $36(0.34)$ & 1.11 & $0.6785-1.8103$ & 0.1686 & 0.6814 \\
\hline \multirow[t]{16}{*}{ TLR4 } & rs 10759931 & Patients smoking $\geq 20$ cigarettes/day & & & & & & \\
\hline & & Total & 118 & 95 & & & & \\
\hline & & AA & $14(0.12)$ & $9(0.09)$ & Ref & & & \\
\hline & & AG & $38(0.32)$ & $35(0.37)$ & 1.43 & $0.5513-3.7234$ & 0.5474 & 0.4594 \\
\hline & & GG & $66(0.56)$ & $51(0.54)$ & 1.20 & $0.482 I-2.9972$ & 0.1561 & 0.6928 \\
\hline & & $A G+G G$ & $104(0.88)$ & $86(0.91)$ & 1.29 & $0.5310-3.1161$ & 0.3123 & 0.5763 \\
\hline & & $A$ & $66(0.28)$ & $53(0.28)$ & Ref & & & \\
\hline & & G & $170(0.72)$ & $137(0.72)$ & 1.00 & $0.6556-1.5363$ & 0.0003 & 0.9870 \\
\hline & rs 10759931 & Patients smoking $<\mathbf{2 0}$ cigarettes/day & & & & & & \\
\hline & & Total & 118 & 57 & & & & \\
\hline & & AA & $14(0.12)$ & $4(0.07)$ & Ref & & & \\
\hline & & AG & $38(0.32)$ & $19(0.33)$ & 1.75 & $0.5063-6.0485$ & 0.7943 & 0.3728 \\
\hline & & GG & $66(0.56)$ & $34(0.60)$ & 1.80 & $0.5509-5.9016$ & 0.9692 & 0.3249 \\
\hline & & $A G+G G$ & $104(0.88)$ & $53(0.93)$ & 1.78 & $0.5595-5.6864$ & 0.9785 & 0.3226 \\
\hline & & A & $66(0.28)$ & $27(0.24)$ & Ref & & & \\
\hline & & G & $170(0.72)$ & $87(0.76)$ & 1.25 & $0.7460-2.0978$ & 0.7223 & 0.3954 \\
\hline
\end{tabular}

Abbreviations: TLR, Toll-like receptor; SNP, single-nucleotide polymorphism; OR, odds ratio; Cl, confidence interval.

Table 6 Allele and genotype frequencies of TLR4 gene polymorphisms in the Riyadh region compared to other populations

\begin{tabular}{|c|c|c|c|c|c|c|c|}
\hline \multirow[t]{2}{*}{ Population } & \multicolumn{3}{|c|}{ Genotype frequency (n) } & \multicolumn{2}{|c|}{ Allele frequency } & \multirow[t]{2}{*}{$\chi^{2}$} & \multirow[t]{2}{*}{$P$-value } \\
\hline & TT & TC & CC & $\mathbf{T}$ & C & & \\
\hline \multicolumn{8}{|c|}{ (A) TLR4 rs2770I50 } \\
\hline CRS $(n=\mid 12)$ & $0.491(55)$ & $0.384(43)$ & $0.125(14)$ & 0.683 & 0.317 & - & - \\
\hline CEU (n=226) & $0.522(1 \mid 8)$ & $0.38 I(86)$ & $0.097(22)$ & 0.712 & 0.288 & 0.3006 & 0.5835 \\
\hline $\mathrm{HCB}(n=86)$ & $0.977(84)$ & $0.023(2)$ & - & 0.988 & 0.012 & 30.0691 & $<0.005$ \\
\hline JPT $(n=88)$ & $1.000(88)$ & - & - & 1.000 & - & 33.9123 & $<0.005$ \\
\hline YRI $(n=226)$ & $0.796(I 80)$ & $0.204(46)$ & - & 0.898 & 0.102 & 24.1620 & $<0.005$ \\
\hline $\operatorname{MEX}(n=100)$ & $0.640(64)$ & $0.260(26)$ & $0.100(10)$ & 0.770 & 0.230 & 1.9997 & 0.1573 \\
\hline MKK $(n=286)$ & $0.720(206)$ & $0.231(66)$ & $0.049(14)$ & 0.836 & 0.164 & II.470I & $<0.005$ \\
\hline \multirow[t]{2}{*}{ TSI $(n=176)$} & $0.625(\mathrm{I} I 0)$ & $0.330(58)$ & $0.045(8)$ & 0.790 & 0.210 & 4.1589 & 0.0414 \\
\hline & AA & AG & GG & A & G & $x^{2}$ & $P$-value \\
\hline \multicolumn{8}{|c|}{ (B) TLR4 rs I 075993 I } \\
\hline CRS $(n=118)$ & $0.119(14)$ & $0.322(38)$ & $0.559(66)$ & 0.280 & 0.720 & - & - \\
\hline$D-0(n=48)$ & - & $0.167(8)$ & $0.833(40)$ & 0.083 & 0.917 & 7.6210 & 0.0058 \\
\hline$E-0(n=38)$ & $0.105(4)$ & $0.526(20)$ & $0.368(14)$ & 0.368 & 0.632 & 1.0657 & 0.3019 \\
\hline CABG $(n=2,156)$ & $0.141(304)$ & $0.458(987)$ & $0.401(865)$ & 0.370 & 0.630 & 3.9379 & 0.0472 \\
\hline
\end{tabular}

Abbreviations: TLR, Toll-like receptor; CABG, coronary artery bypass graft; CEU, Utah residents with Northern and Western European ancestry from the CEPH collection; CEPH, Centre d"Etude du Polymorphisme Humain; HCB, Han Chinese in Beijing, China; JPT, Japanese in Tokyo, Japan; YRI, Yoruba in Ibadan, Nigeria; MEX, Mexican ancestry in Los Angeles, CA, USA; MKK, Maasai in Kinyawa, Kenya; TSI, Toscans in Italy; CRS, Saudi population residing in the Riyadh region of central Saudi Arabia; D-0, from Coriell Human Variation Panel - African American; E-0, from Coriell CEPH/Utah Pedigree - Caucasian; CABG, North American. 


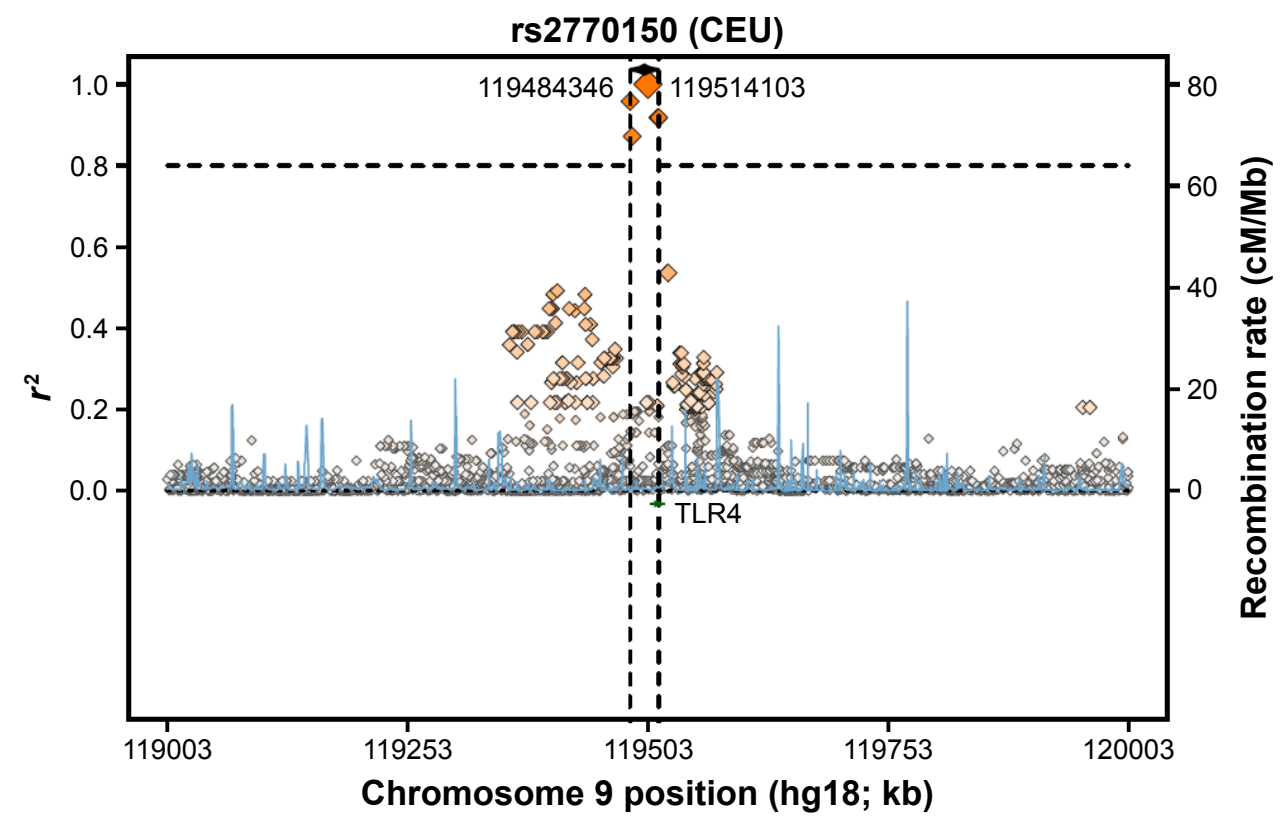

Figure I Regional LD plot for the TLR4 rs2770I50 SNP.

Abbreviations: LD, linkage disequilibrium; TLR, Toll-like receptor; SNP, single-nucleotide polymorphism; CEU, Utah residents with Northern and Western European ancestry from the CEPH collection; CEPH, Centre d"Etude du Polymorphisme Humain.

(coronary artery bypass graft; $P<0.05$ ). Additionally, we constructed linkage disequilibrium plots for both the TLR4 rs2770150 and rs10759931 SNPs using SNP Annotation and Proxy Search (SNAP; http://www.broadinstitute.org/ mpg/snap/ldplot.php; Figures 1 and 2). The maximum $r^{2}$ values for rs2770150 and rs10759931 were 0.958 and 0.965 , respectively.

\section{Discussion}

Several studies have assessed the genetic changes following cigarette smoke exposure, typically identifying changes in innate immunity genes. Others have evaluated changes in gene expression of gingival epithelial cells in response to cigarette smoke. ${ }^{42}$ Previous studies showed a clear link between smoking cigarettes and the pathogenesis of many

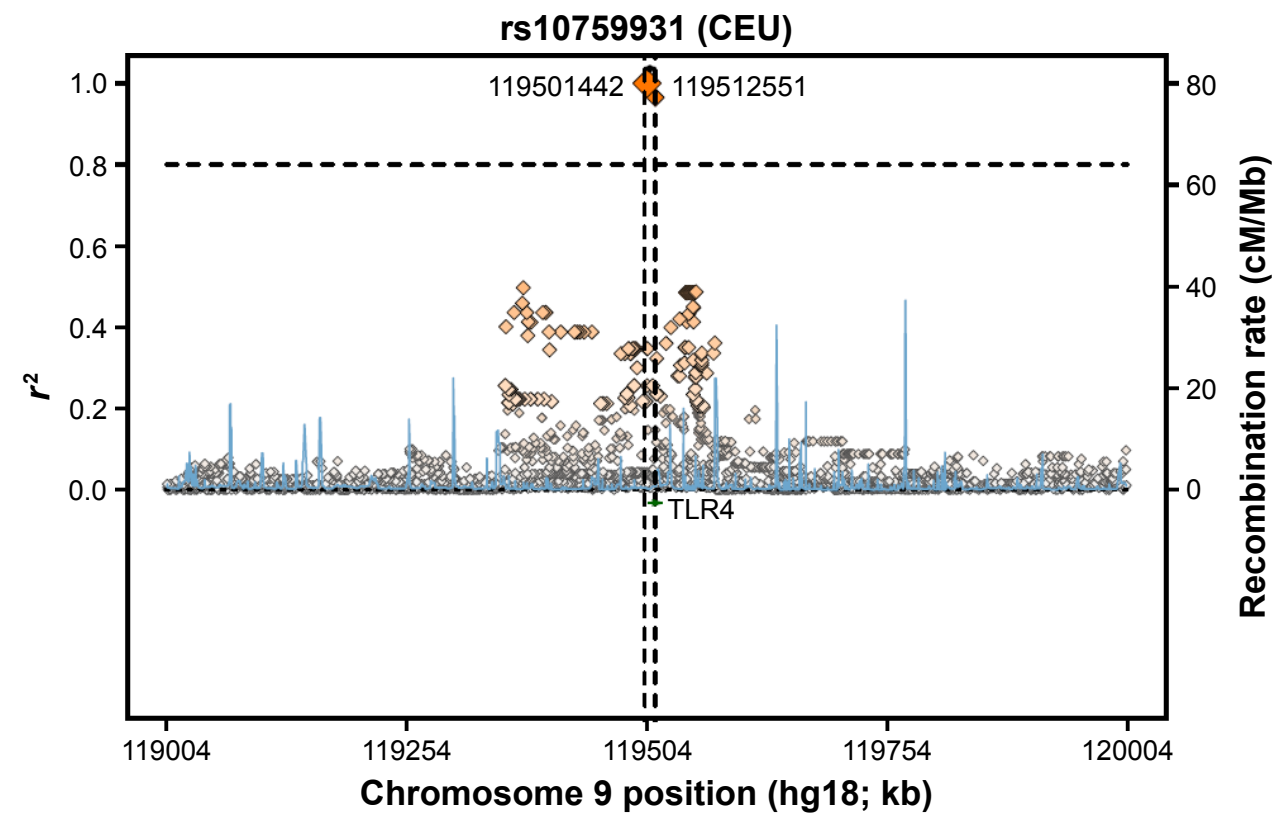

Figure 2 Regional LD plot for rs 1075993 I SNP in TLR4.

Abbreviations: LD, linkage disequilibrium; SNP, single-nucleotide polymorphism; TLR, Toll-like receptor; CEU, Utah residents with Northern and Western European ancestry from the CEPH collection; CEPH, Centre d"Etude du Polymorphisme Humain. 
diseases, in particular, COPD, oral cancer, and periodontal disease. Additionally, we have previously shown that smoking tobacco affects TLR4 expression via different pathways. ${ }^{42}$ Impairment of TLR4 signaling becomes evident through the presence of SNPs that are associated with cancer susceptibility, and we have recently described an association between TLR4 polymorphism and colon cancer development. ${ }^{27}$ Although they could have either positive or negative effects, polymorphisms in TLR 4 have been reported in various diseases. ${ }^{25,26,43,44}$ These diseases and others have been found to be caused by tobacco smoke. ${ }^{31-33}$

In the present study, we showed that smoking has a slight effect on the rs2770150 and rs10759931 SNPs of TLR4. However, no significant association was observed between cigarette smoking and the genetic distribution of the SNPs investigated. Our results are contradictory to those previously published that show that the TLR4 rs2770150 and rs10759931 SNPs are associated with different diseases. ${ }^{27-30}$ The lack of significant results may be explained by the lack of association between smoking and genetic variation in TLR4 rs2770150 and rs10759931 SNPs. Other SNPs in $T L R 4$, especially those in regulatory regions or exons, may be associated with various diseases related to smoking. Thus, although these SNPs may not be related to smoking-induced diseases, we recommend performing other studies on SNPs located in the exons of TLR4.

Comparison of the data for the TLR4 rs2770150 SNP between the Riyadh population and other populations showed a pattern similar to that reported for SNPs located in other genes, such as the Thr241Met SNP in X-ray repair crosscomplementing group 3 (XRCC3), ${ }^{45}$ which reinforces the historical hypothesis of early human migration out of Africa. ${ }^{46}$ The imbalance between the protective/affective effects of polymorphism is a key factor in the development of smokingrelated diseases in human beings. Further investigations in larger populations of the same or mixed ethnicity could help to define the effects of smoking on different genes involved in the human innate immune system. Further insight into the genetic factors affected by smoking could lead to new approaches for cessation or prevention of smoking and treatment of many diseases caused by tobacco.

\section{Acknowledgment}

This study was supported by funding from the NSTIP Strategic Technologies Program (number 12 MED 2443) in the Kingdom of Saudi Arabia.

\section{Disclosure}

The authors report no conflicts of interest in this work.

\section{References}

1. Levy JA. The importance of the innate immune system in controlling HIV infection and disease. Trends Immunol. 2001;22(6):312-316.

2. Bachmann MF, Kopf M. On the role of the innate immunity in autoimmune disease. J Exp Med. 2001;193(12):F47-F50.

3. Nowarski R, Gagliani N, Huber S, Flavell RA. Innate immune cells in inflammation and cancer. Cancer Immunol Res. 2013;1(2):77-84.

4. Schroder NW, Arditi M. The role of innate immunity in the pathogenesis of asthma: evidence for the involvement of Toll-like receptor signaling. J Endotoxin Res. 2007;13(5):305-312.

5. Sweeney CM, Tobin AM, Kirby B. Innate immunity in the pathogenesis of psoriasis. Arch Dermatol Res. 2011;303(10):691-705.

6. Heneka MT, Golenbock DT, Latz E. Innate immunity in Alzheimer's disease. Nat Immunol. 2015;16(3):229-236.

7. Heneka MT, Kummer MP, Latz E. Innate immune activation in neurodegenerative disease. Nat Rev Immunol. 2014;14(7):463-477.

8. Akira S, Uematsu S, Takeuchi O. Pathogen recognition and innate immunity. Cell. 2006;124(4):783-801.

9. Oldenburg M, Krüger A, Ferstl R, et al. TLR13 recognizes bacterial 23S rRNA devoid of erythromycin resistance-forming modification. Science. 2012;337(6098):1111-1115.

10. Sugawara Y, Uehara A, Fujimoto Y, et al. Toll-like receptors, NOD1, and NOD2 in oral epithelial cells. J Dent Res. 2006;85(6): 524-529.

11. Rich AM, Hussaini HM, Parachuru VP, Seymour GJ. Toll-like receptors and cancer, particularly oral squamous cell carcinoma. Front Immunol. 2014;5:464.

12. Narayanan KB, Park HH. Toll/interleukin-1 receptor (TIR) domain-mediated cellular signaling pathways. Apoptosis. 2015;20(2): 196-209.

13. Maru GB, Gandhi K, Ramchandani A, Kumar G. The role of inflammation in skin cancer. Adv Exp Med Biol. 2014;816:437-469.

14. Sun Q, Zhang Q, Xiao HP, Bai C. Toll-like receptor polymorphisms and tuberculosis susceptibility: a comprehensive meta-analysis. J Huazhong Univ Sci Technolog Med Sci. 2015;35(2):157-168.

15. Skevaki C, Pararas M, Kostelidou K, Tsakris A, Routsias JG. Single nucleotide polymorphisms of Toll-like receptors and susceptibility to infectious diseases. Clin Exp Immunol. 2015;180(2):165-177.

16. Takahashi M, Chen Z, Watanabe K, et al. Toll-like receptor 2 gene polymorphisms associated with aggressive periodontitis in Japanese. Open Dent J. 2011;5:190-194.

17. Chan M, Ji SM, Liaw CS, et al. Association of common genetic variants with breast cancer risk and clinicopathological characteristics in a Chinese population. Breast Cancer Res Treat. 2012;136(1): 209-220.

18. Thomas PE, Klinger R, Furlong LI, Hofmann-Apitius M, Friedrich CM. Challenges in the association of human single nucleotide polymorphism mentions with unique database identifiers. BMC Bioinformatics. 2011; 12(suppl 4):S4.

19. Collins FS, Brooks LD, Chakravarti A. A DNA polymorphism discovery resource for research on human genetic variation. Genome Res. 1998; 8(12):1229-1231.

20. Ke X, Taylor MS, Cardon LR. Singleton SNPs in the human genome and implications for genome-wide association studies. Eur J Hum Genet. 2008;16(4):506-515.

21. Zheng SL, Augustsson-Bälter K, Chang B, et al. Sequence variants of Toll-like receptor 4 are associated with prostate cancer risk: results from the Cancer Prostate in Sweden Study. Cancer Res. 2004;64(8): 2918-2922.

22. Kutikhin AG, Yuzhalin AE. Are Toll-like receptor gene polymorphisms associated with prostate cancer? Cancer Manag Res. 2012;4:23-29.

23. Kilding R, Akil M, Till S, et al. A biologically important single nucleotide polymorphism within the Toll-like receptor-4 gene is not associated with rheumatoid arthritis. Clin Exp Rheumatol. 2003;21(3):340-342.

24. Weng PH, Huang YL, Page JH, et al. Polymorphisms of an innate immune gene, Toll-like receptor 4 , and aggressive prostate cancer risk: a systematic review and meta-analysis. PLoS One. 2014;9(10): e110569. 
25. El-Omar EM, Ng MT, Hold GL. Polymorphisms in Toll-like receptor genes and risk of cancer. Oncogene. 2008;27(2):244-252.

26. Xu Y, Jiang Z, Huang J, Meng Q, Coh P, Tao L. The association between Toll-like receptor 4 polymorphisms and diabetic retinopathy in Chinese patients with type 2 diabetes. Br J Ophthalmol. 2015;99(9): 1301-1305.

27. Semlali A, Reddy Parine N, Arafah M, et al. Expression and polymorphism of Toll-like receptor 4 and effect on NF-kappaB mediated inflammation in colon cancer patients. PLoS One. 2016;11(1): e0146333.

28. Banus S, Bottema RW, Siezen CL, et al. Toll-like receptor 4 polymorphism associated with the response to whole-cell pertussis vaccination in children from the KOALA study. Clin Vaccine Immunol. 2007; 14(10):1377-1380.

29. Kerkhof M, Postma DS, Brunekreef B, et al. Toll-like receptor 2 and 4 genes influence susceptibility to adverse effects of traffic-related air pollution on childhood asthma. Thorax. 2010;65(8):690-697.

30. Wu L, Hu Y, Li D, Jiang W, Xu B. Screening Toll-like receptor markers to predict latent tuberculosis infection and subsequent tuberculosis disease in a Chinese population. BMC Med Genet. 2015;16:19.

31. Gilliland FD, Islam T, Berhane $\mathrm{K}$, et al. Regular smoking and asthma incidence in adolescents. Am J Respir Crit Care Med. 2006;174(10): 1094-1100.

32. He G, Li Y, Zhao F, et al. The prevalence and incidence of latent tuberculosis infection and its associated factors among village doctors in China. PLoS One. 2015;10(5):e0124097.

33. Ferrara G, Murray M, Winthrop K, et al. Risk factors associated with pulmonary tuberculosis: smoking, diabetes and anti-TNF alpha drugs. Curr Opin Pulm Med. 2012;18(3):233-240.

34. Bozinovski S, Vlahos R, Anthony D, et al. COPD and squamous cell lung cancer: aberrant inflammation and immunity is the common link. Br J Pharmacol. 2015;173(4):635-648.

35. Gutierrez A, Suh R, Abtin F, Genshaft S, Brown K. Lung cancer screening. Semin Intervent Radiol. 2013;30(2):114-120.
36. Corral R, Lewinger JP, Van Den Berg D, et al. Comprehensive analyses of DNA repair pathways, smoking and bladder cancer risk in Los Angeles and Shanghai. Int J Cancer. 2014;135(2):335-347.

37. El-Zaatari ZM, Chami HA, Zaatari GS. Health effects associated with waterpipe smoking. Tob Control. 2015;24(suppl 1):i31-i43.

38. Steenaard RV, Ligthart S, Stolk L, et al. Tobacco smoking is associated with methylation of genes related to coronary artery disease. Clin Epigenetics. 2015;7(1):54.

39. Acevedo A, Brodsky L, Andino R. Mutational and fitness landscapes of an RNA virus revealed through population sequencing. Nature. 2014;505(7485):686-690.

40. Farrell A, Coleman BI, Benenati B, et al. Whole genome profiling of spontaneous and chemically induced mutations in Toxoplasma gondii. BMC Genomics. 2014;15:354.

41. Alanazi M, Pathan AA, Abduljaleel Z, et al. Association between PARP-1 V762A polymorphism and breast cancer susceptibility in Saudi population. PLoS One. 2013;8(12):e85541.

42. Semlali A, Witoled C, Alanazi M, Rouabhia M. Whole cigarette smoke increased the expression of TLRs, HBDs, and proinflammory cytokines by human gingival epithelial cells through different signaling pathways. PLoS One. 2012;7(12):e52614.

43. Zhu L, Yuan H, Jiang T, Wang R, Ma H, Zhang S. Association of TLR2 and TLR4 polymorphisms with risk of cancer: a meta-analysis. PLoS One. 2013;8(12):e82858.

44. Minmin S, Xiaoqian X, Hao C, et al. Single nucleotide polymorphisms of Toll-like receptor 4 decrease the risk of development of hepatocellular carcinoma. PLoS One. 2011;6(4):e19466.

45. Alanazi M, Pathan AA, Ajaj SA, et al. DNA repair genes XRCC1, $\mathrm{XRCC} 3, \mathrm{XPD}$, and OGG1 polymorphisms among the central region population of Saudi Arabia. Biol Res. 2013;46(2):161-167.

46. Alsmadi O, John SE, Thareja G, et al. Genome at juncture of early human migration: a systematic analysis of two whole genomes and thirteen exomes from Kuwaiti population subgroup of inferred Saudi Arabian tribe ancestry. PLoS One. 2014;9(6):e99069.
OncoTargets and Therapy

\section{Publish your work in this journal}

OncoTargets and Therapy is an international, peer-reviewed, open access journal focusing on the pathological basis of all cancers, potential targets for therapy and treatment protocols employed to improve the management of cancer patients. The journal also focuses on the impact of management programs and new therapeutic agents and protocols on

\section{Dovepress}

patient perspectives such as quality of life, adherence and satisfaction The manuscript management system is completely online and includes a very quick and fair peer-review system, which is all easy to use. Visit http://www.dovepress.com/testimonials.php to read real quotes from published authors. 